\title{
On the nature of the peripheral nerve lesions associated with acute intermittent porphyria
}

\author{
J. B. CAVANAGH AND R. S. MELLICK ${ }^{1}$ \\ From the Department of Pathology, Guy's Hospital Medical School, London
}

A survey of the literature on the anatomical basis for paralysis associated with acute intermittent porphyria yields a confused picture that sheds little light on how this comes about. Erbslöh (1903) originally described changes in the peripheral nerves of a patient paralysed after sulphonal medication which were undoubtedly Wallerian in type. Mason, Courville, and Ziskind (1933), in their comprehensive review of the subject, stated that axons and myelin sheaths are destroyed in a patchy manner, implying thereby, first that they could see no meaningful pattern in the types of nerve fibres involved, and secondly, that the myelin degeneration was secondary in type. Hierons (1957) echoed this view and in addition stressed that all authors were in agreement that the nerve cells in the spinal cord and root ganglia, although they might be either normal or chromatolytic, were never destroyed.

A new view of the nature of the process was suggested by Denny-Brown and Sciarra (1945) when they reported two patients in whose peripheral nerves the only changes apparently present were oedema and 'segmental' demyelination. Unfortunately the latter change was not well depicted in their photomicrographs. They postulated an ischaemic cause for these changes. Gibson and Goldberg (1956) interpreted the massive demyelination apparent in the peripheral nerves of their five patients as primary in nature, stating in support of this that many nerve fibres devoid of myelin could be seen in the demyelinated areas.

Clinically the condition is chiefly a motor paralysis, sensory disturbances being minimal and late, if they appear at all. If this were indeed a primary demyelination of peripheral nerve fibres it is difficult to imagine, in the present state of our knowledge, how it could be that only the myelin sheaths of motor nerves in mixed nerve bundles come to be affected in this way.

This report contains some observations on the pattern of nerve fibre damage that were obtained in an effort to resolve this uncertainty, the necessity 'Present address: M.R.C. Research Group in Applied Neurobiology, Institute of Neurology, 8/11, Queen Square, London, W.C.1. for doing so springing from two causes. First, if the management of such patients is to be rationally handled then it would seem to be essential to know whether the regrowth of only the myelin sheath from. Schwann cells was necessary or whether the re- $\overrightarrow{\vec{H}}$ growth of axons, perhaps over long distances, was to be looked for. It would be anticipated that the former would be a relatively rapid process and relatively complete, while the latter would be slow, uncertain N $_{\infty}$ and incomplete. Secondly, if any search for the biochemical mechanisms underlying these changes to be made it would be important a priori to know 0 whether the Schwann cells were primarily at fault, of whether this fault lay in the metabolic pathwaysrelated to their specific functions.

THE CASE MATERIAL

CASE 1 A.W., a man aged 23 years, died at Guy Hospital (P.M. 155/62) on 2 May 1962. One sister has porphobilinogenuria and has mild peripheral sensoryo disturbances. He was admitted to hospital 21 days before death with abdominal pain and a history of constipation. $\bar{\partial}$ He was considered to have intestinal obstruction and was given soluble phenobarbitone (gr. 3) intramuscularly, $\mathbb{D}$ fluid replacement therapy for electrolyte imbalance, and pethidine. Six days later porphobilinogen was found in $\overline{\mathrm{O}}$ the urine. Weakness was complained of the next day (14 days before death) and he had urinary retention and pain in the right hypochondrium. However, neurologicalo examination did not reveal objective weakness and no positive neurological signs were observed. The next day the tendon jerks in both arms and in the left leg were: found to be reduced. Four days later (10 days before 3 death) all limb reflexes were absent, but there were still ${ }_{0}$ neither objective signs of weakness nor any sensory윽 anomalies. The next day definite generalized muscular weakness developed. Seven days before death respiratory음 paralysis ensued and although he was maintained in as respirator he developed a lung infection from which he died.

CASE 2 M.A., a woman aged 31, died at Guy's Hospita (P.M. 192/62) on 31 May 1962. Twenty-three weeks? before death she was admitted to hospital complaining of 
malaise for seven days, vomiting for three days, and abdominal pain for 12 hours. Appendicectomy was carried out three days later. On discharge she said that she was 'floppy but better'. Two days afterwards she was readmitted with colicky abdominal pain and constipation, and within three days (21 weeks before death) severe weakness of both arms and legs developed so that she could neither raise her arms nor walk. This was considered to be hysterical at first, but porphyrins were noted in the urine three weeks later. She remained in hospital for 13 weeks, but on discharge (seven weeks before death) although she could walk she still could not feed herself. One month later she obtained some Nembutal and took 12 gr. over 10 days. By the morning after the first dose (three weeks before death) she was unable to walk and her paresis increased until, when she was admitted to Guy's Hospital 11 days before death, she had no limb movements apart from a little at the shoulders. There was marked general muscular wasting. Before she died she developed bilateral facial weakness of lower motor neurone type.

CASE 3 A.K. was a man aged 31 years. One brother had died from acute intermittent porphyria and one male cousin had symptomless porphobilinogenuria. One year before death he had an episode of abdominal and back pain, vomiting, and the passing of dark urine. Seven weeks before death he suffered a similar attack, complicated by urinary retention. He was also considered at this time to have an abnormal personality and auditory hallucinations. For this he was given phenobarbitone gr. 3 daily and four days later weakness began affecting his arms more than his legs. Barbiturates were, however, continued until admission to a mental asylum where porphyrins were noted in the urine. Barbiturates were then stopped and he was transferred to Guy's Hospital two weeks before death. Considerable wasting of all muscles was noted on admission with marked hypotonia and severe paresis of both upper and lower limbs. This weakness affected the proximal muscles more than the distal. No sensory loss was observed, but the muscles were painful to pressure. He subsequently developed weakness of bulbar and respiratory muscles and died from a lung infection on 11 December 1963 (P.M. 479/63).

CASE 4 D.H. was a man aged 33 years. He had no family history of porphyria. Two years before death attacks of unconsciousness began which were treated with phenobarbitone (gr. $\frac{1}{2}$ ) twice daily. This he continued to take over the next 19 months. In May 1962, four months before death, his urine became dark and a few days later he developed generalized aching, anorexia, and constipation. Abdominal pain and vomiting followed in a few days. He was correctly diagnosed by his doctor and on admission to hospital barbiturates were stopped. Examination showed blood pressure $170 / 115 \mathrm{~mm}$. $\mathrm{Hg}$, but no neurological abnormality. Weakness of the outstretched arms developed two weeks later but this did not progress. Two months before death he developed marked fatiguability and weakness especially of the shoulder girdle and the back muscles. The legs at this stage were normal but within a week these too became affected, and he developed hoarseness and dysphagia. Six weeks before he died he was transferred to the National Hospital, Queen Square, where total paralysis of the upper limbs and severe paresis of the lower limbs was found. There was marked hypotonia but no muscular wasting; although tingling was complained of sensation was normal. The muscles supplied by the seventh, ninth, tenth, and twelfth cranial nerves were also paretic. One month before death no voluntary movement at any joint was possible, and muscle wasting became progressively more pronounced. He was maintained in a respirator until 24 September 1962 when he died.

\section{THE PATHOLOGICAL MATERIAL}

At post-mortem examination muscles were dissected from the hand (first lumbrical, flexor and abductor pollicis), forearm (brachioradialis and flexor digitorum longus), arm (biceps and deltoid), and cervical paraspinal region, allowed to adhere to library cards and then fixed in formol saline. The ulnar and median nerves were similarly taken onto a library card with slight tension before being fixed. The spinal cord, with as many spinal root ganglia as possible, was dissected and fixed before cutting up. Blocks were taken from the spinal cord at cervical, upper and lower thoracic, lumbar and sacral levels and prepared for sections $(15 \mu)$ in paraffin in the usual way. Lengths of peripheral nerve and spinal root ganglia, the former cut in longitudinal and transverse planes, were also taken. Haematoxylin and eosin, cresyl fast violet and Glees and Marsland's stain for axons were used on all blocks, and in addition myelin stains on the peripheral nerve tissues.

From each muscle frozen sections, $50 \mu$ thick, were cut; six were stained with sudan black B counterstained with carmalum (Cavanagh, Passingham, and Vogt, 1964) and six with Schofield's modification of Bielschowsky's method for axons.

Nerves at each level were teased under a dissecting microscope and then stained with sudan black B or with oil red $\mathrm{O}$, after which they were further teased in glycerine until individual fibres could be clearly seen. Portions of both sensory and motor nerve roots from the cauda equina were also taken for teasing in this way.

\section{RESULTS WITH TEASED NERVES AND SPINAL ROOTS}

In all four cases only normal fibres or fibres undergoing Wallerian degeneration were found in the peripheral nerves and in the spinal roots. Segmental degeneration, either as whole internodal breakdown or as paranodal damage, was not found in any specimen. The fragmenting sheaths and fibres were found in all stages of degeneration from the very earliest formation of ovoids to later stages where very little lipid was evident in the bands of Büngner. The finding of early degenerative changes, even so long after the onset of the paresis as in cases 3 and 4 , was somewhat unsuspected and indicated that the damaging process was not completed with the onset 
of paralysis. Cell multiplication characteristic of Wallerian degeneration was present at all these stages of myelin breakdown. Silver impregnation was also attempted in a few instances on the teased fibres and in these many very fine nerve fibres were seen among those fragmenting; from their fineness and their wandering course these were taken to be regenerative sprouts but without myelin sheaths.

The spinal roots were sampled from regions both close to and far away from the parent neurones. Thus, in the ventral roots the fibres nearest to the spinal cord showed no or very little degeneration in any case, but in the samples taken close to the dura, and thus furthest away from the spinal cord, there were many degenerating fibres in cases 3 and 4, but none were seen in cases 1 and 2. The reverse distribution was found in the sensory roots; very few fibres were found to be degenerating in the samples from close to the ganglia, but in case 3 there were moderate numbers and in case 4 there were many degenerating fibres in samples taken from near the spinal cord (Fig. 1a and b). There were a few degenerating fibres found in the gracile tracts of the

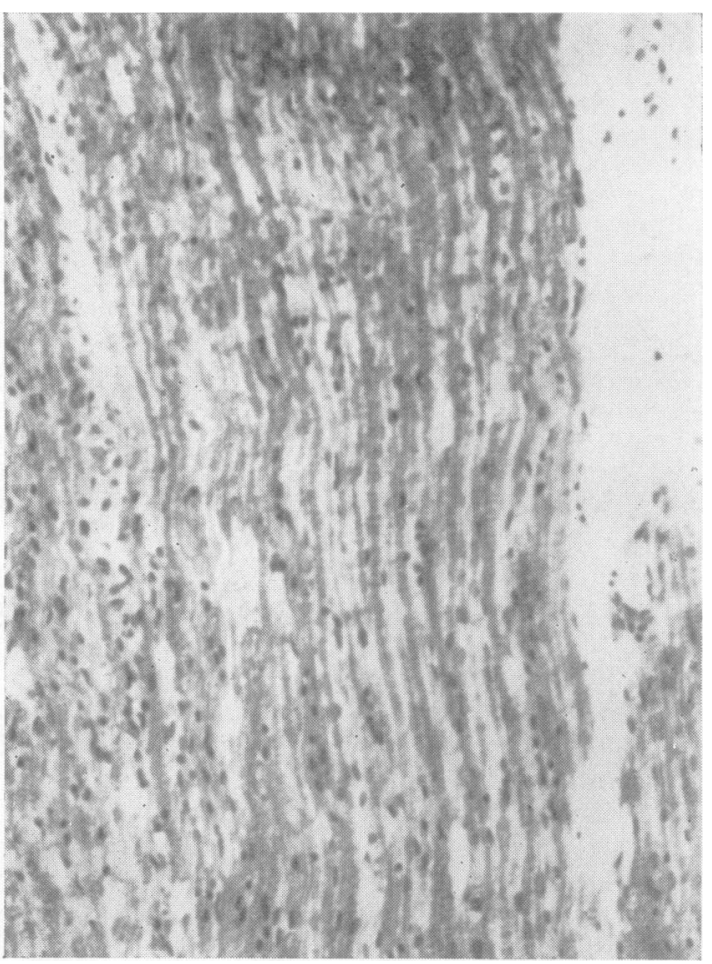

FIG. 1a.

FIG. 1. Dorsal lumbar spinal root (case 4).

(a) Near ganglion where very few fibres are degenerating, and (b) near spinal cord where very many degenerating fibres and numerous foam cells are seen. Both sections stained with haematoxylin and eosin $\times 250$. spinal cord in case 4 , which were presumably derived $\bar{z}$ from these and similarly degenerating dorsal root $\stackrel{\mathbb{D}}{=}$ fibres.

\section{RESULTS WITH FROZEN SECTIONS OF MUSCLES}

Preparations of muscles stained with sudan black $\mathrm{B} \stackrel{\text { ก }}{\text {. }}$ are useful in such a problem for several purposes, $v i z$. , the examination of large (mixed) intramuscular nerve bundles; the examination of the preterminal $\overrightarrow{\vec{F}}$ motor nerve bundles and fibres; and the examination $\stackrel{\vec{F}}{\stackrel{P}{9}}$ of the innervation of the muscle spindles and other sensory nerve endings. The muscle spindles have a $\frac{\bar{G}}{\bar{n}}$ characteristic variety of myelinated nerve fibres $\frac{0}{\sigma}$ running to them. First, there is the large diameter $\stackrel{\oplus}{\varrho}$ primary sensory fibre which may branch both before of and after entering the capsule of the spindle until it $\vec{\circ}$ ultimately loses its myelin sheath near the equatorial region of the spindle. The coils of the annulo- $\vec{\omega}$ spiral ending can usually be seen by this method, $\stackrel{S}{S}$ probably by virtue of the mitochondria that they contain. Second, there is frequently present in the juxta-equatorial region of the spindle, secondary $\mathrm{N}_{\infty}$

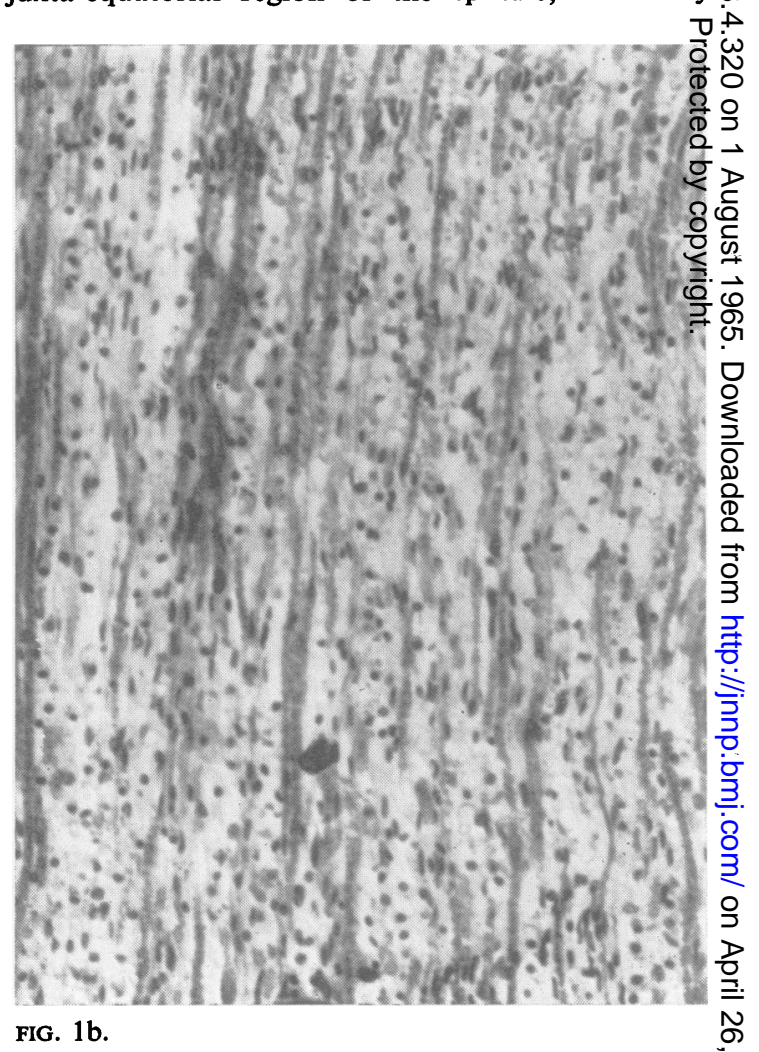
D. 윽 $\rightarrow$ 
sensory ('flower spray') endings served by fibres of medium size. The naked endings of these can sometimes be seen in these preparations as grey flakes lying between the intrafusal muscle fibres in the juxta-equatorial regions. Secondary sensory fibres are found less frequently in muscles of the hand than in the larger muscles of the limb. Third, there are small diameter fibres often running in the capsule of the organ and ending at the polar regions which are the motor ( $\gamma$-efferent) fibres to the spindle (Boyd, 1962). The nerve fibres running to Golgi tendon organs are usually solitary in their course through the muscle. On entrance into the organ they lose their myelin sheaths and grey flakes, which probably represent the terminal naked nerve swellings, may be seen scattered within the organ (Cavanagh et al., 1964).

The outstanding feature of the examination of the muscles in these four cases was the extremely severe loss of nerve fibres and myelin sheaths in all the muscles examined. This was often far in excess of what would have been considered likely from the examination of nerve trunks. One can only conclude that most of the surviving nerve fibres in these latter were probably sensory (Table II).

MOTOR FIBRES Total or almost total denervation in the samples of muscle examined from the hand, forearm, and arm was the rule in cases 2,3 , and 4 (Table II). In case 1 there were a few surviving nerve fibres still evident in the palmar muscles and in the muscles from the upper arm. This extremely severe denervation met with in cases 2,3 , and 4 was most striking in the preparations stained with sudan black B. In these the branching preterminal nerve bundles could be clearly seen, but in large part they contained no nerve fibres but only scattered lipid droplets (Fig. 2). In small mixed bundles it was common to see one or a few fibres of large diameter remaining amongst the lipid debris (Fig. 3): these almost certainly were either fibres from Golgi tendon organs, or from muscle spindles; they were usually associated with spindles elsewhere in the muscle in which these structures were intact. In such denervated muscles it was not uncommon also to encounter larger bundles with a mixed population of nerve fibre sizes most of which appeared to be normal: it was impossible to be certain of the nature of these bundles, but in palmar muscles where they were most common it is likely that these were sensory bundles 'en passage' through the muscle.

Preparations stained for axons paralleled the myelin preparations in the distribution and amount of the damaged fibres, with the exception that in cases 1 and 2 occasional extremely fine fibres were found taking a meandering course along the nerve bundles

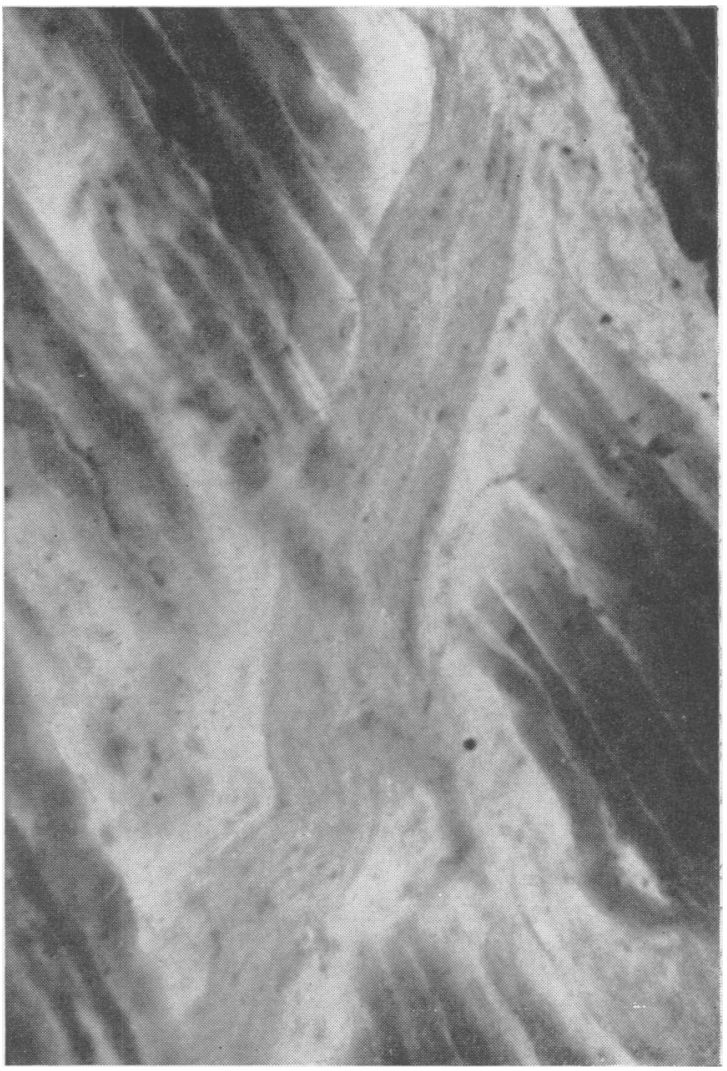

FIG. 2. Lumbrical muscle (case 3). Intramuscular nerve bundle showing total loss of all fibres and only scattered fine lipid droplets. Sudan black $B \times 90$.

(Fig. 4). These were interpreted as probably regenerating nerve sprouts. It was only in the cervical paraspinal muscles that normal motor nerve terminals were found with any frequency, both in sudan black and silver preparations. In case 4, however, there was complete denervation in this region as well.

SENSORY FIBRES The presence of normal primary spindle afferent fibres in the palmar muscles was common in case 1 , infrequent in cases 2 and 3 , and not found in case 4 (Table II). In the last case, although the spindles were readily visible they were all completely denervated. In case 2 and 3 completely denervated spindles were found as well as partially denervated (Fig. 5) and also normal looking spindles (Fig. 6). Because of the relatively low spindle density in the other muscles of the arm less information was obtained about these, but from the diameter of the surviving fibres in the small mixed nerve bundles in these muscles, it is probable that the same 


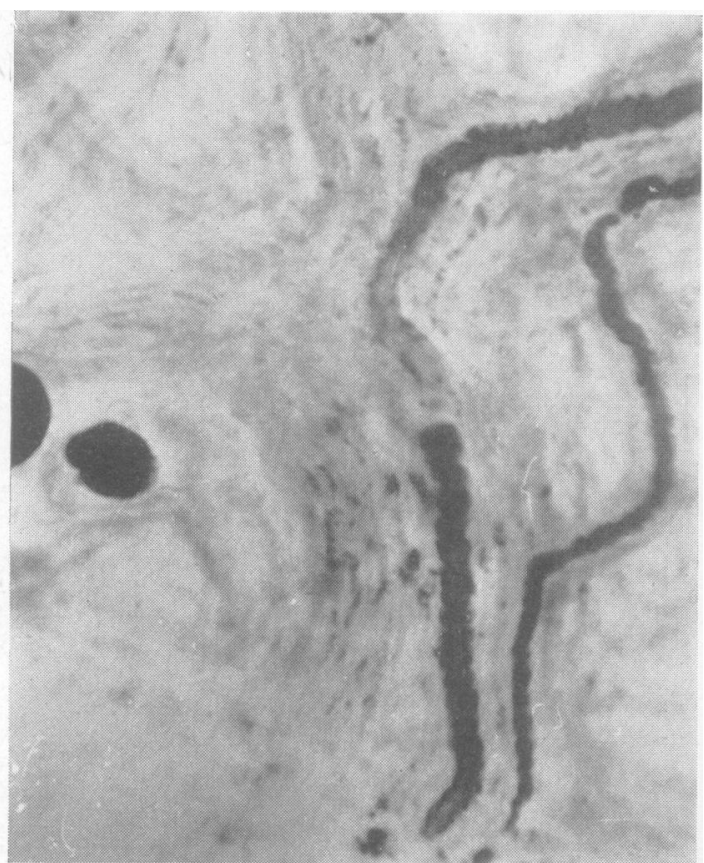

FIG. 3 .

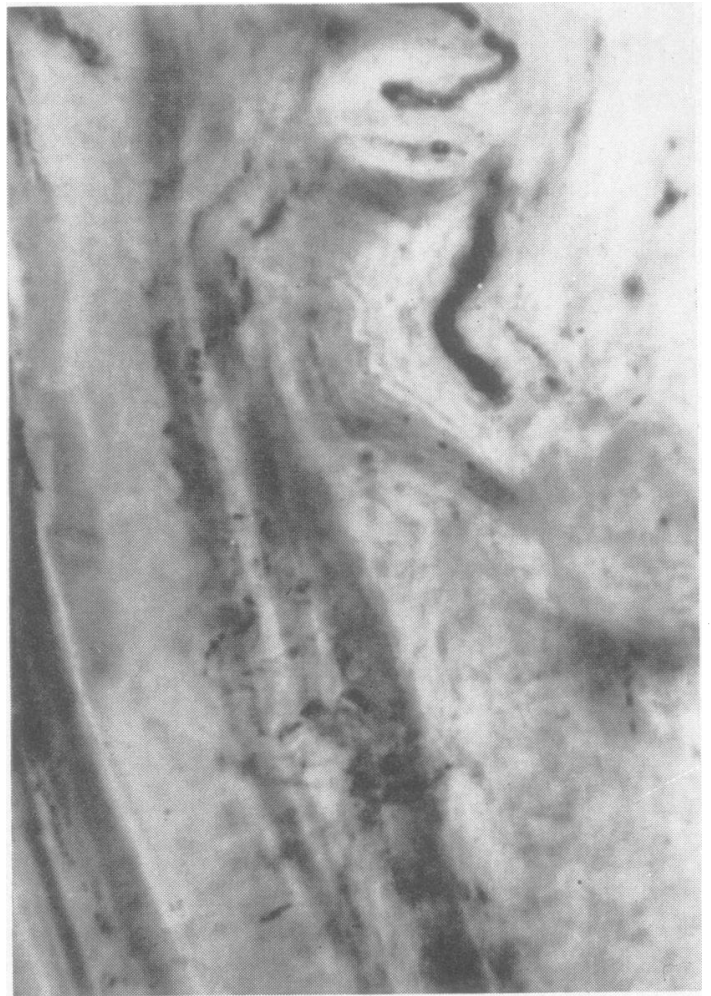

FIG. 3. Biceps muscle (case 3). Intramuscular nerve bundle showing loss of all fibres except two, both of large diameter. Sudan black $B \times 250$.

FIG. 4. Lumbrical muscle (case 1). Silver impregnation of lumbrical muscle showing a few thick surviving axons, many granules of degenerating fibres, and several extremely thin, unmyelinated fibres, probably regeneration sprouts. Glees $\times 300$.

FIG. 5. Lumbrical muscle (case 3). Muscle spindle with Wallerian fragmentation of the primary sensory fibre. 윽 Sudan black $B \times 90$.

FIG. 5 . 


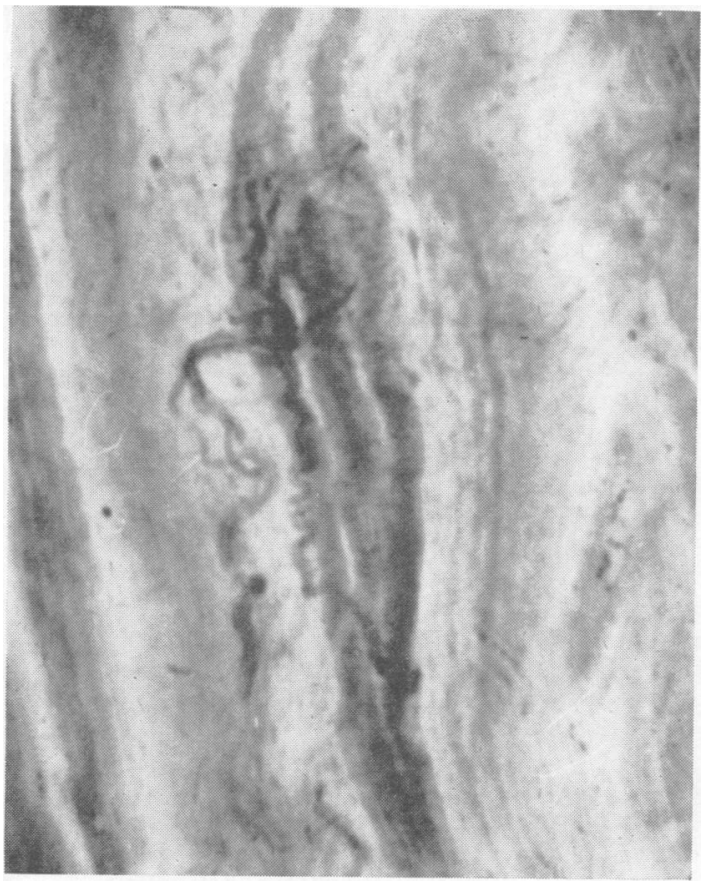

FIG. 6. Lumbrical muscle spindle (case 3) with an apparently normal primary sensory fibre. Sudan black $B \times 450$.

also held, namely, that in case 1 there was probably very mild damage, in cases 2 and 3 the damage was probably more severe, while in case 4 complete damage was unquestionable.

Very few Golgi tendon organs were found in any of the muscles examined. Since these are not uncommonly present in normal palmar muscles it may be assumed that these too were affected.

\section{CHANGES IN MOTOR AND SENSORY NEURONES}

No reduction in numbers of anterior horn cells was evident at any level of the spinal cord examined. Chromatolysis was seen, however, in a few large neurones in both the cervical and lumbar levels in case 2 and in many large neurones in case 4 . No chromatolysis was found in the thoracic levels in any case. No nerve cell loss or neuronophagia was seen in any case, but vacuolated neurones were found in the lumbar region of cases 3 and 4 .

In sensory ganglia chromatolysis is normally less readily apparent than in motor neurones, but despite this it was considered that chromatolysis was probably present in lumbar and in cervical ganglia of cases 3 and 4 (Fig. 7) and also possibly in case 2 . No nerve cell loss was detectable in any ganglion.

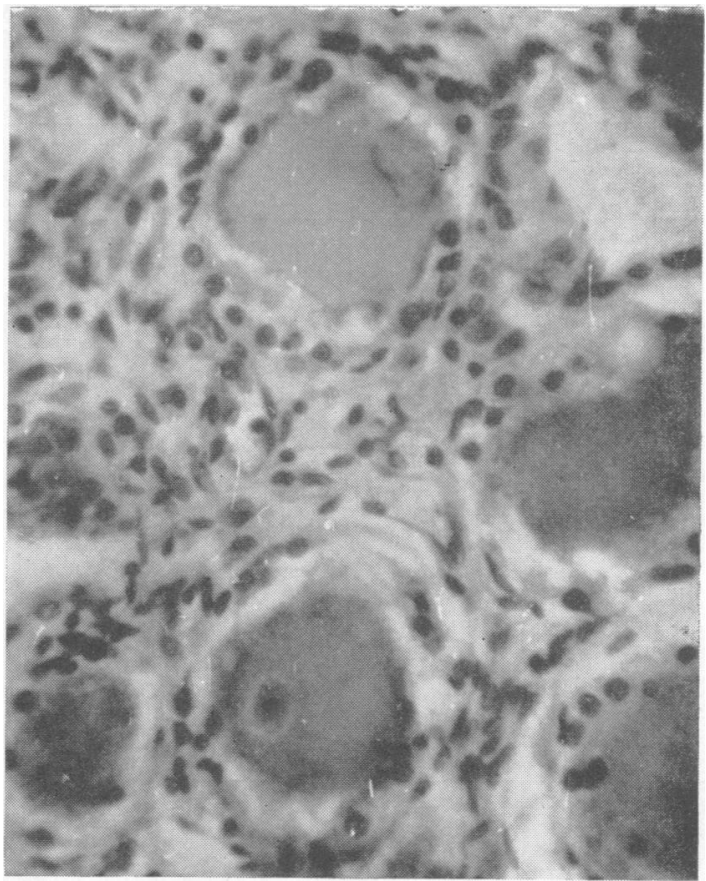

FIG. 7. Chromatolysis of nerve cell in dorsal spinal root ganglion (case 3). Cresyl fast violet $\times 450$.

\section{MUSCLE DENERVATION ATROPHY}

Despite widespread loss of axons, denervation atrophy was not striking in any but palmar muscles. Here there was extensive atrophy in all four cases, minimal in case 1 and maximal in case 4, and varying in its intensity and completeness in the others. Reduction in muscle fibre diameters from this cause was certainly present in other arm muscles but it was patchy and not widespread. Denervation atrophy was least evident in the paraspinal muscles in all cases.

\section{DISCUSSION}

Correlation of the evolution of the clinical features of these four cases (Table I) with the degree and distribution of the anatomical damage present in the muscles (Table II) allows us to draw certain conclusions about the natural history of the nerve lesions that have not, perhaps, received sufficient emphasis in previous discussions on the subject.

All four cases showed gross denervation of muscle regardless of whether the history of paresis was short (case 1, two weeks) or long (cases 3 and 4). There was no evidence found to support the idea that the paresis in this condition is due to a primary demyelinating process. All the evidence suggested 
TABLE I

CLINICAL FEATURES AND THEIR TIME RELATIONS

\begin{tabular}{|c|c|c|c|c|c|c|c|c|c|c|c|c|c|}
\hline \multirow[b]{2}{*}{$\begin{array}{l}\text { Case } \\
\text { No. }\end{array}$} & \multicolumn{5}{|c|}{ Previous Attacks } & \multicolumn{8}{|l|}{ Final Attacks } \\
\hline & $\begin{array}{l}\text { Age } \\
\text { (yr.) }\end{array}$ & Sex & $\begin{array}{l}\text { Family } \\
\text { History of } \\
\text { Porphyria }\end{array}$ & $\begin{array}{l}\text { Abdominal } \\
\text { Pain }\end{array}$ & Paresis & $\begin{array}{l}\text { Barbiturate } \\
\text { Taken }\end{array}$ & $\begin{array}{l}\text { Abdominal } \\
\text { Symptoms }\end{array}$ & $\begin{array}{l}\text { Porphyrins } \\
\text { in } \\
\text { Urine }\end{array}$ & $\begin{array}{l}\text { Subjective } \\
\text { Weakness }\end{array}$ & $\begin{array}{l}\text { Loss of } \\
\text { Reflexes }\end{array}$ & $\begin{array}{l}\text { Objective } \\
\text { Weakness }\end{array}$ & $\begin{array}{l}\text { Proximal } \\
\text { or } \\
\text { Distal }\end{array}$ & $\begin{array}{l}\text { Objective } \\
\text { Sensory } \\
\text { Loss }\end{array}$ \\
\hline $\begin{array}{l}\text { Case } 1 \\
\text { A.W. }\end{array}$ & 23 & $\delta$ & + & No & No & $\begin{array}{l}\text { Once only } \\
3 \text { gr. i.m. } \\
3 \text { wk. }\end{array}$ & 3 wk. & 2 wk. & 2 wk. & 10 days & $\begin{array}{l}9 \text { days } \\
\text { arms } \\
>\text { legs }\end{array}$ & Both & No \\
\hline $\begin{array}{l}\text { Case } 2 \\
\text { M.A. }\end{array}$ & 31 & 우 & - & $\begin{array}{l}\text { Yes } \\
23 \text { wk. }\end{array}$ & Yes & $\begin{array}{l}\text { Nembutal } \\
12 \text { gr. over } \\
10 \text { days } \\
3 \text { wk. }\end{array}$ & 21 wk. & 18 wk. & $\begin{array}{l}21 \text { wk. } \\
\text { and } \\
3 \text { wk. }\end{array}$ & $\begin{array}{l}21 \text { wk. } \\
\text { and } \\
3 \text { wk. }\end{array}$ & $\begin{array}{l}21 \text { wk. } \\
\text { and } \\
3 \text { wk. } \\
\text { arms } \\
>\text { legs }\end{array}$ & $\begin{array}{l}\text { Proximal } \\
>\text { distal }\end{array}$ & No \\
\hline $\begin{array}{l}\text { Case } 3 \\
\text { A.K. }\end{array}$ & 31 & ప & + & $\begin{array}{l}\text { Yes } \\
\text { (1 yr.) }\end{array}$ & No & $\begin{array}{l}1 \text { gr. t.d.s. } \\
6 \text { wk.- } \\
3 \text { wk. }\end{array}$ & 7 wk. & 3 wk. & 7 wk. & 2 wk. & $\begin{array}{l}2 \text { wk. } \\
\text { arms } \\
>\text { legs }\end{array}$ & $\begin{array}{l}\text { Proximal } \\
>\text { distal }\end{array}$ & No \\
\hline $\begin{array}{l}\text { Case } 4 \\
\text { D.H. }\end{array}$ & 33 & 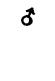 & - & No & No & $\begin{array}{l}\frac{1}{2} \text { gr. b.d. } \\
\text { ( } 23 \text { mth.- } \\
4 \text { mth.) }\end{array}$ & 4 mth. & $4 \mathrm{mth}$ & $2 \mathrm{mth}$ & 2 mth. & $\begin{array}{l}2 \text { wk. } \\
\text { arms } \\
>\text { legs }\end{array}$ & $\begin{array}{l}\text { Proximal } \\
>\text { distal }\end{array}$ & No \\
\hline
\end{tabular}

${ }^{1}$ All periods are times before death.

'See text.

\section{TABLE II}

\begin{tabular}{|c|c|c|c|c|c|}
\hline $\begin{array}{l}\text { Muscle } \\
\text { Features }\end{array}$ & $\begin{array}{l}\text { Case } \\
\text { No. }\end{array}$ & $\begin{array}{l}\text { Paraspinal } \\
\text { Cervical }\end{array}$ & $\begin{array}{l}\text { Upper } \\
\text { Arm }\end{array}$ & $\begin{array}{l}\text { Lower } \\
\text { Arm }\end{array}$ & Palmar \\
\hline $\begin{array}{l}\text { Mixed } \\
\text { intra- } \\
\text { muscular } \\
\text { nerves }\end{array}$ & $\begin{array}{l}1 \\
2 \\
3 \\
4\end{array}$ & $\frac{2}{2}$ & $\begin{array}{l}2 \\
3 \\
3 \\
4\end{array}$ & $\begin{array}{l}-3 \\
3 \\
4\end{array}$ & $\begin{array}{l}3 \\
3 \\
3 \\
4\end{array}$ \\
\hline $\begin{array}{l}\text { Motor } \\
\text { terminal } \\
\text { fibres }\end{array}$ & $\begin{array}{l}1 \\
2 \\
3 \\
4\end{array}$ & $\frac{3}{2}$ & $\begin{array}{l}3 \\
4 \\
4 \\
4\end{array}$ & $\begin{array}{l}-4 \\
4 \\
4\end{array}$ & $\begin{array}{l}4 \\
4 \\
4 \\
4\end{array}$ \\
\hline $\begin{array}{l}\text { Sensory } \\
\text { fibres }^{1}\end{array}$ & $\begin{array}{l}1 \\
2 \\
3 \\
4\end{array}$ & $\frac{-}{1}$ & $\begin{array}{l}- \\
-\end{array}$ & $\frac{-}{4}$ & $\begin{array}{l}1 \\
3 \\
3 \\
4\end{array}$ \\
\hline $\begin{array}{l}\text { Muscle } \\
\text { fibre } \\
\text { wasting }\end{array}$ & $\begin{array}{l}1 \\
2 \\
3 \\
4\end{array}$ & $\begin{array}{r}2 \\
1 \\
2\end{array}$ & $\begin{array}{r}2 \\
2 \\
1 \\
3\end{array}$ & $\begin{array}{l}-2 \\
2 \\
3\end{array}$ & $\begin{array}{l}2 \\
3 \\
3 \\
4\end{array}$ \\
\hline \multicolumn{6}{|c|}{$\begin{array}{l}1=\text { normal fibres } \\
2=\text { many normal fibres } \\
3=\text { few normal fibres } \\
4=\text { no normal fibres } \\
\text { Assessed on sensory fibres to muscle spindles. } \\
{ }^{2} \text { Graded } 1 \text { normal, } 4 \text { very severe wasting. }\end{array}$} \\
\hline
\end{tabular}

that the degeneration in the nerves was in fact of the 'dying back' type. Although distal muscles in all cases showed more severe denervation which was of longer standing, as suggested by the relative degrees of denervation atrophy of the muscle fibres, the weakness, when assessed by neurological examination, was in all but case 1 considered to be most marked and earliest in the proximal muscle groups. This discrepancy is of considerable importance when the pathogenetic significance of proximal versus distal weakness is considered in a neuropathic disorder. In a truly distal neuropathy where longest fibres are affected earliest and most extensively, the weakness appears always to be distal, e.g., ö-cresyl phosphate neuropathy (Cavanagh, 1963; 1964 a and $b$ ). There is evidence for believing that the 'dying back' process in porphyria neuropathy is not behaving in the same manner as the organo-phosphorus lesion; thus the primary sensory fibres fromp spindles are least affected in porphyria but mosథ and earliest affected in organo-phosphorus neurog toxicity. Rather it would appear that in porphyrie neuropathy there is no marked selectivity for long fibres and thus the 'dying back' occurs more or less irrespective of distance from the spinal cord. If such a circumstance size of motor units must become a determining factor as to whether weakness occurs $\overrightarrow{8}$ in proximal regions early or not. Thus, if the 'dying $\mathrm{s}$ back' proceeds to the points of branching in muscles with large motor units a greater number of denervated muscle fibres will result than when the same happens in muscles with small motor units.

The present findings clearly indicate the special sensitivity of motor nerves to degeneration in this condition. This is in complete accord with the clinical picture. But it should be emphasized that the changes are by no means restricted to motor fibres. $\frac{\text { \% }}{5}$ In all four cases damage to sensory fibres was also widespread in the muscles examined. This inference is, however, drawn largely from the examination? of muscle spindles, and further information is $\frac{3}{3}$ clearly needed about the state of the cutaneous and other sensory nerves and their fibres. There were, however, unequivocal changes in the sensory roots in cases 3 and 4 , although no sensory disturbances $\frac{9}{3}$ were clinically appreciable. Hierons (1957) showed $D$ in one of his cases that the posterior columns (gracile tracts) might show loss of fibres and similar $N$ changes of minor degree were present in our case 4 . Goldberg (1959) found moreover that 19 out of his 50 cases showed some degree of impaired sensation, $\omega$ 
so that it is probable that much more damage to sensory fibres might be found by appropriate sampling. Drury's (1956) finding of gross denervation in a cutaneous nerve from the foot in one case would tend to substantiate this conclusion.

Many other clinical features of this condition noted by Hierons (1957) are explicable on the basis of this condition being a relatively acute and massive degeneration of the 'dying back' type. Many authors (Rothman, 1926; Mason et al., 1933; - Berg, 1945; Denny-Brown and Sciarra, 1945) have noted that the peripheral nerves at necropsy might show no changes at all. This would seem to be particularly so if death occurred within a short time of the onset of the paresis. Berg's patient died within two days. We do not know how rapid is the ascent of the degeneration nor how long it takes to reach the levels of the major nerve trunks usually sampled at post-mortem examination. The occurrence of the changes of early Wallerian degeneration in case 4 , who had been paralysed for the longest period, suggests that the process is a progressive one rather than one in which a portion of the nerve fibre is suddenly lost with degeneration distal to this. Additional evidence for this view is the finding of changes in the spinal roots only in those cases surviving longest.

Hierons (1957) comments upon the strikingly rapid and complete recovery from virtually complete paralysis that may sometimes occur. It is suggested that in such an instance the distances to be covered during regeneration must be short. By contrast, there are many cases in the literature, such as the patient of Harbitz (1924), in which recovery even after many years is very incomplete. Presumably the same laws apply in the 'dying back' process as after a nerve crush, namely, that the efficiency of re-innervation is inversely proportional to the distance needed to be covered (Young, 1942).

The observations reported here place the primary defect in motor neurones and to a lesser degree in the sensory cells. The hypothesis put forward by Goldberg (1959) and Goldberg and Rimington (1962), which demands an intermediary step leading to the disturbance of myelin metabolism, would therefore be inessential. Their concept of a lesion in the metabolism of acetate, which at the present time would appear to be sufficient to account for their biochemical findings (de Matteis and Rimington, 1962), would be adequate also to explain the special involvement of nerve cells and the production of this type of degenerative process. It has been emphasized elsewhere (Cavanagh, 1963; 1964b) that conditions showing the 'dying back' process in which a likely cause is known often show a metabolic lesion in the pathways concerned with the transfer of energy in the cell. What is of special interest here is the selectivity of the process to the cells of the anterior horn and spinal ganglia, suggesting the operation of additional pathogenetic factors.

\section{SUMMARY}

Four cases of acute intermittent porphyria suffering from severe paresis were examined at necropsy. Particular attention was paid to the state of innervation of the arm muscles. Extensive degeneration of motor and sensory nerve fibres was consistently found, but no evidence of primary or segmental demyelination. The pattern of the pathological process was consistent with it being a distal degeneration of nerve fibres and indicated that the defect probably fell most heavily on nerve rather than Schwann cells. This concept is considered to fit closely with the natural history of the neurological defects.

We wish to thank Professor R. W. Gilliatt, Professor W. J. H. Butterfield, Dr. I. T. Grant, and Dr. C. L. Joiner for allowing us to have access to the clinical notes of these cases, and Dr. I. Berkinshaw Smith and Professor W. Blackwood for post-mortem material.

\section{REFERENCES}

Berg. M. (1945). Acute porphyria. Clinical and pathological observations. Arch. intern. Med., 76, 335-340.

Boyd, I. A. (1962). The structure and innervation of the nuclear bag muscle fibre system and the nuclear chain muscle fibre system in mammalian muscle spindles. Phil. Trans. B., 245, 81-136.

Cavanagh, J. B. (1963). Organo-phosphorus neurotoxicity: A model 'dying back' process comparable to certain human neurological disorders. Guy's Hosp. Rep., 112, 303-319.

- (1964a). Peripheral nerve changes in ortho-cresyl phosphate poisoning in the cat. J. Path. Bact., 87, 365-383.

- (1964b). The significance of the 'dying back' process in experimental and human neurological disease. Int. Rev. exp. Path., 3, 219-267.

_- Passingham, R. J., and Vogt, J. A. (1964). Staining of sensory and motor nerves in muscles with sudan black B.J. Path. Bact., 88, 89-92.

Denny-Brown, D., and Sciarra, D. (1945). Changes in the nervous system in acute porphyria. Brain, 68, 1-16.

de Matteis, F., and Rimington, C. (1962). The biochemical disturbance in acute intermittent and experimental porphyria. Lancet, 1, 1332-1334.

Drury, R. A. B. (1956). A nerve biopsy in acute intermittent porphyria. J. Path. Bact., 71, 511.

Erbslöh, W. (1903). Zur pathologie und pathologischen Anatomie der toxischen Polyneuritis nach Sulfonalgebrauch. Dtsch. $Z$. Nervenheilk., 23, 197-204.

Gibson, J. B., and Goldberg, A. (1956). The neuropathology of acute porphyria. J. Path. Bact., 71, 495-509.

Golberg, A. (1959). Acute intermittent porphyria. Quart. J. Med., 28. 183-209.

- $\longrightarrow$ and Rimington, C. (1962). Diseases of Porphyrin Metabolism. Thomas, Springfield, Illinois.

Harbitz, F. (1924). Hematoporphyrinuria as an independent disease ('hematoporphyria') and as a symptom of liver disease and intoxications. Arch. intern. Med., 33, 632-642.

Hierons, R. (1957). Changes in the nervous system in acute porphyria. Brain, 80, 176-192.

Mason, V. R. Courville, C., and Ziskind, E. (1933). The porphyrins in human disease. Medicine (Baltimore), 12, 355-439.

Rothman, P. E. (1926). Hematoporphyrinuria-report of two cases Amer. J. Dis. Child., 32, 219-225.

Young, J. Z. (1942). The functional repair of nervous tissue. Physiol. Rev., 22, 318-374.

.

